\title{
Benefit of permanent non-fire refugia for Lepidoptera conservation in fire-managed sites
}

\author{
Ann B. Swengel · Scott R. Swengel
}

Received: 4 May 2006/ Accepted: 8 October 2006/Published online: 15 December 2006

(C) Retained by Author 2006

\begin{abstract}
From the early 1990s through 2005, we conducted butterfly transect surveys annually at the same sites in three regions of Wisconsin. We compared specialist butterfly population indices at three sites where a permanent non-fire refugium (a unit kept unburned through cycles of rotational fire elsewhere in the site) was established during this study to indices at comparison sites (which had consistent management throughout this study) in the same region. At Crex Meadows (12,180 ha), all significant changes in specialist numbers skewed toward relatively higher abundance in the refugium (14 ha, last burned in 1988) during the later period (1998-2005) versus 10 comparison subsites (fire-managed in both periods) than expected from observations in the earlier period (1991-97). The same pattern occurred in the refugium (4 ha) at Bauer-Brockway (125 ha), after the rest of that unit (9 ha) had its first management fire. Population trends were positive in these refugia, while the comparison sites usually had less favorable trends, or otherwise had similar trends. At Muralt Bluff (25 ha), regal fritillaries (Speyeria idalia) were more concentrated in the refugium (3 ha, last burned in 1991) during the earlier period but were more abundant in both periods in the refugium than the other units there (fire-managed in both periods). In the earlier period at Muralt Bluff, this species significantly declined, the opposite trend of comparison sites (which always had never-burned refugia), but significantly increased in the later period, similar to comparison sites. The refugium did not benefit Ottoe skipper (Hesperia
\end{abstract}

A. B. Swengel $(\varangle) \cdot$ S. R. Swengel

909 Birch Street, Baraboo, WI 53913, USA

e-mail: swengel@naba.org ottoe), which declined significantly in the earlier period and was not recorded in the later period. Formerly burned units began functioning as refugia only $>6-8$ years after last fire and continued to increase in benefit for years after that. In fire-managed and fireprone sites, we recommend the creation of permanent non-fire refugia for Lepidoptera conservation, placed where the most specialists will benefit and managed unintensively (e.g. mowing) if needed.

Keywords Lycaeides melissa samuelis - Speyeria idalia · Fire-free refugium · Butterfly conservation . Fire management

\section{Introduction}

North America's tallgrass prairie contains predominately herbaceous flora. Savanna (trees and brush interspersed with herbaceous patches) mixes with and occurs along the eastern and northern margins of tallgrass prairie (Curtis 1959; Anderson 1982; Nuzzo 1986). This is usually called "oak savanna" except for more northerly "pine barrens" on very sandy soil. Since European contact in North America, it is estimated that about $99 \%$ of tallgrass prairie and oak savanna has been destroyed primarily by conversion to agriculture (Curtis 1959; Nuzzo 1986; Solecki and Toney 1986). Barrens have also declined but not to the same degree (Curtis 1959; Borgerding et al. 1995). Unmanaged patches of prairie and savanna today often become overgrown by woody species (sometimes called succession) and accumulation of plant litter. As a result, periodic "disturbances" or processes, disrupted today because of ecosystem destruction and 
fragmentation, are widely considered necessary for prairies and savannas to persist (Vogl 1974; Shuey 1997).

Because the decimation of prairie and savanna preceded their scientific study, it is difficult to reconstruct these prehistoric processes (Curtis 1959; Anderson 1982). Nonetheless, it is widely assumed that management for these ecosystems depends upon re-establishing these processes (Vogl 1974; Nuzzo 1986; Borgerding et al. 1995).

Based on some botanical research, fire has been inferred by many to be the dominant process maintaining the openness (uncanopied condition) of prairie and savanna (Sauer 1950; Stewart 1956; Vogl 1974; Nuzzo 1986), although the primary cause (lightning or humans), season, and frequency of these fires remains in dispute (Russell 1983; Higgins 1984, 1986; Howe 1994; Umbanhowar 1996). Prairie existed for millions of years before humans arrived in North America (Weaver 1954). Pollen and other studies find few charcoal layers, fire scars, or other evidence of landscape fires prehistorically, with past fires separated by hundreds of years (Baker et al. 1996) and only becoming frequent post-Columbus, especially after European settlement (King 1981; Cole et al. 1995; Dieffenbacher-Krall 1996). Alternative theories assert that the openness of these ecosystems was maintained by climate (Clements 1916; Transeau 1935; Borchert 1950; Weaver 1954; King 1981), herbivory by grazers and browsers (Larson 1940; England and DeVos 1969; Moore 1988), seed consumption and mechanical destruction of forests by billions of now extinct passenger pigeons (Ectopistes migratorius) (Ellsworth and McComb 2003), or a combination of climate and/or herbivory with fire, soil, and/or topography (Anderson 1982; Nuzzo 1986; Howe 1994; Knapp et al. 1999).

The effects of ecosystem management with fire on insects are subjects both of research and controversy. Butterflies specialized to live in native prairie and savanna vegetation are often assumed to be fire-adapted, given their restriction to ecosystems considered firedependent. Observations of particular butterfly populations or sites have been viewed as corroboration of that expectation (Panzer 1988, 2002; Dana 1991; Shuey 1997). Other studies have contested the assumption that frequent extensive burning benefits (or does not irretrievably harm) butterflies requiring native herbaceous vegetation, and recommend greater reliance on alternative managements like mowing, haying, light grazing, and/or brush-cutting (Opler 1981; Orwig 1992; Schlicht and Orwig 1992; Swengel 1996a, 1998b; Schlicht 2001; Swengel and Swengel 2001b). Most above-ground insects appear to die in fires and specialists have the most negative short-term response, needing to rebuild their populations from unburned refugia (Swengel 1996a, 2001; Harper et al. 2000; Panzer 2002).

This paper presents analyses of butterfly responses to a "permanent non-fire refugium." This cumbersome term signifies that a management unit (although possibly quite small) is kept unburned through cycle after cycle of rotational fire management elsewhere in the site, not just temporarily unburned for that year or that rotation. These refugia are managed some other way, such as with mowing, brush-cutting, and/or spot- (not broadcast) herbiciding if needed to control specific areas of brush and/or non-native plants. This approach is different from other kinds of "refugia" in the literature. A management unit called "unburned" sometimes only indicates that the unit was not burned since the last growing season (e.g. Harper et al. 2000; Panzer 2002). Sometimes a portion of a burn unit is shielded from fire when the remainder of the unit is burned (e.g. Kwilosz and Knutson 1999; New et al. 2000; Panzer 2003), but whether any areas are left unburned and where may vary from burn to burn.

Here, we present long-term annual population monitoring results for habitat-specialist butterflies in prairies and pine barrens. "Habitat" is construed here as the places/conditions where a particular species lives (not simply a caterpillar food plant patch or a general vegetation type), and is intended to be compatible with "habitat" as in Dennis (2004). For those species listed as threatened or endangered at the state or federal levels, legal regulation of site management occurs, encouraging the creation of permanent non-fire refugia and greater use of mechanical cutting than burning (Bureau of Endangered Resources 1999; U.S. Fish and Wildlife Service 2003). At three sites, a permanent non-fire refugium (hereafter "refugium") was established during our study. Results from other ("comparison") monitoring sites in the same region are used to distinguish regional fluctuations and trends from patterns at the individual sites (e.g. as in Pollard and Yates 1993). When the individual site was managed differently than the comparison sites, a difference in butterfly population trend between them can be attributed to that difference in management. When a site was managed with fire earlier in the study but developed a refugium later (or vice versa), we also compare results at that site between the earlier and later periods.

These are our analytical questions:

1. Does a specialist butterfly species increase in abundance in the refugium relative to fire-managed 
comparison sites (i.e. is management in the refugium relatively more favorable than fire management)?

2. How small can a refugium be and still be effective when the rest of the site remains in fire management?

3. Can more than one specialist benefit from the same refugium?

4. Is a never-burned refugium more effective than a formerly burned unit?

5. After how many fire-free years does a burned unit become effective as a refugium, if at all?

6. How far outside the refugium does the refugium influence specialist butterfly abundance?

7. Do butterfly populations fluctuate more (unfavorable for viability) or less (a stabilizing influence) in the refugium relative to fire-managed comparison sites?

These results should provide useful information about the ecology and conservation of these species. They also test the efficacy of legally regulating site management for listed species, both for those species and for co-occurring specialist species.

\section{Methods}

\section{Study sites and surveys}

We conducted butterfly transect surveys along like routes within each site each visit (similar to Pollard 1977), as described in Swengel (1996a, 1998b) (Appendix 1). All butterfly species found were counted, but survey times and locations were selected to study a focal habitat-specialist species (Swengel and Swengel 2000, 2001a, 2005): frosted elfin (Callophrys irus, listed in Wisconsin as threatened), Karner blue (Lycaeides melissa samuelis, federally listed as endangered), or regal fritillary (Speyeria idalia, listed in Wisconsin as endangered) (Bureau of Endangered Resources 1999; U.S. Fish and Wildlife Service 2003). We assessed relative abundance of wild lupine (Lupinus perennis) (Fabaceae), caterpillar food plant for the Karner blue rangewide and frosted elfin in Wisconsin, based on these categories and arithmetic ratios: superabundant (100,000), abundant (10,000), common (1000), uncommon (100), and rare (10). We surveyed for another focal species, phlox moth (Schinia indiana), listed in Wisconsin as endangered (Bureau of Endangered Resources 1999), by examining its caterpillar food plant, downy phlox (Phlox pilosa) (Polemoniaceae), especially flowers and flower buds (Swengel and
Swengel 1999). The focal species occurred at all monitoring sites we designated for that species.

Our population index is the peak survey count per site per brood, standardized to survey distance, to create an observation rate $/ \mathrm{km}$ (relative abundance) for comparisons among sites. Thomas (1984) found that one survey during the main flight period (period when in the adult life stage) is adequate for producing valid indices for comparisons of relative abundance within and among sites. Nearly all our peak butterfly surveys occurred within the weather parameters of the British Butterfly Monitoring Scheme but our peak surveys occurred in a much wider range of times of day (0700-1830 h CST) (Pollard and Yates 1993).

All sites in our long-term monitoring dataset appropriate for this study are analyzed here (Table 1). Refugia were selected because they supported focal study species and other specialist butterfly species, were readily excludable from fire (due to already established burn unit boundaries and/or a feature such as a creek, ravine, pipeline right-of-way, and/or road), and usually had less encroachment by brush and nonnative plants (reducing the need for management).

At Crex Meadows (Fig. 1), pine barrens and oak savanna were managed with broadcast fire and mowing, and targeted wick herbiciding affecting only brush to be removed. The refugium (about $14 \mathrm{ha}$ ) had been burned in 1972, 1974, 1979, 1984, and 1988 (Pete Engman unpubl. data). During the 1990s, managers mapped lupine to ensure that unburned lupines occupied by Karner blues occurred near the edge of burned areas (Paul Kooiker pers. commun.).

Bauer-Brockway Barrens (Fig. 2) is naturally regenerated county forest dedicated to conservation management since 2000. The entire site is inside the perimeter of a 7000 ha 1977 wildfire but within $0.5-1.1 \mathrm{~km}$ of this perimeter. Once the firebreak was installed in unit 1 in spring 2001, we divided our survey route into "inside" the fire-managed area ( 9 ha) and "outside" the burned area (4 contiguous ha of neverfire-managed refugium). Only for frosted elfins had we kept detailed location information for each individual observed in unit 1 before this burn; thus, analysis of individuals observed in "inside" versus "outside" was possible only for frosted elfin. Hand-cutting of pines occurred in this and the other never-fire-managed refugium (unit 4, 15 ha) as well as the fire-managed area. Units 2, 3, and 5 had similar vegetation but no active management. The comparison sites occurred in county and state forests, state wildlife areas, and roadside and powerline rights-of-way (verges). One comparison site had two rotations of fire management 
Table 1 Study sites for the permanent non-fire refugium (at left margin) and comparison sites (indented), their ownership, county, size, year our monitoring began, and vegetation surveyed

\begin{tabular}{|c|c|c|c|c|c|}
\hline Site & Vegetation $^{\mathrm{a}}$ & Ownership $^{b}$ & County & Size $(h a)^{c}$ & Year \\
\hline Crex Meadows Wildlife Area & $\mathrm{B}, \mathrm{S}$ & WDNR & Burnett & 12,180 & 1991 \\
\hline Burnett County Forest & $\mathrm{B}, \mathrm{S}$ & County & Burnett & 43,070 & 1991 \\
\hline Bauer-Brockway Barrens & $\mathrm{B}$ & County, WDNR & Jackson & 125 & 1992 \\
\hline Jackson County Forest & $\mathrm{B}$ & County & Jackson & 48,921 & 1992 \\
\hline Black River State Forest & $\mathrm{B}$ & State & Jackson & 27,142 & 1990 \\
\hline Sandhill Wildlife Area & $\mathrm{B}$ & State & Wood & 3826 & 1992 \\
\hline Highway X right-of-way (verge) & $\mathrm{B}$ & County & Wood & 8 & 1990 \\
\hline Muralt Bluff Prairie $^{\mathrm{d}}$ & $\mathrm{P}$ & County & Green & 25 & 1990 \\
\hline Thomson Prairie complex: & & & & 131 & \\
\hline Thomson original acquisition & $\mathrm{P}, \mathrm{F}$ & $\mathrm{TNC}$ & Dane, Iowa & 24 & 1990 \\
\hline Thousand's II Point Prairie & $\mathrm{P}$ & TNC & Iowa & 2 & 1990 \\
\hline Thomson subsequent acquisition & $\mathrm{P}, \mathrm{F}$ & TNC & Iowa & 33 & 1992 \\
\hline Hogback Prairie & $\mathrm{P}$ & Private, then TNC & Crawford & ca. 35 & 1992 \\
\hline Buena Vista Grassland & $\mathrm{F}$ & State, Foundation & Portage & $>4766$ & 1997 \\
\hline
\end{tabular}

${ }^{\text {a }}$ Surveyed vegetation: $\mathrm{B}$ = pine barren, $\mathrm{F}$ = old field, $\mathrm{P}=$ never-plowed prairie, $\mathrm{S}$ = oak savanna. Other vegetation types also occur in most sites

b TNC $=$ The Nature Conservancy, WDNR = Wisconsin Department of Natural Resources

c Obtained from Wisconsin Chapter of The Nature Conservancy (1988, 2006), Wisconsin Department of Natural Resources (1998, 2006, and in litt.), Toepfer (2003), Wisconsin County Forest Association (2006). Hogback size is our estimate; remaining 356 ha in preserve is farmland, old fields, forests, or disjunct small hillsides

d Oliver Prairie (1.6 ha, owned by University of Wisconsin) is within $2 \mathrm{~km}$ south of Muralt Bluff

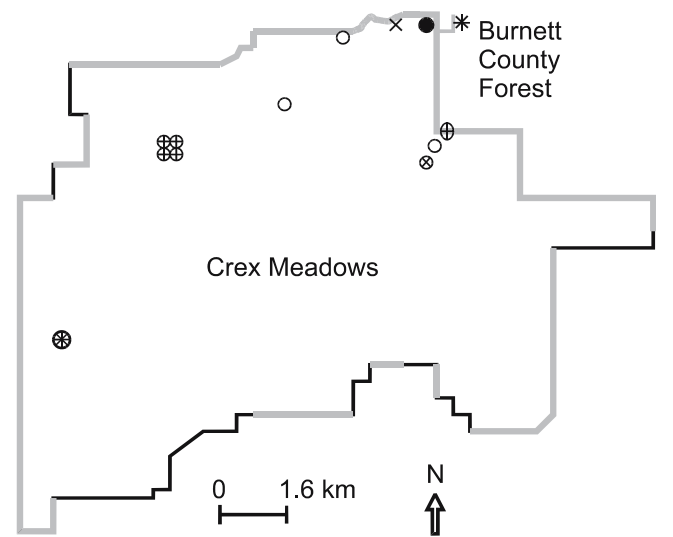

\begin{tabular}{ll} 
& public road bordering Crex Meadows \\
\hline & portion of public road in Burnett County Forest \\
\hline & border of Crex Meadows \\
\hline & refugium \\
$+\quad$ comparison subsite (summer butterflies) \\
$+\quad$ comparison subsite (spring butterflies) \\
$\times \quad$ comparison subsite (phlox moth)
\end{tabular}

Fig. 1 Map of Crex Meadows and adjoining Burnett County Forest. The refugium is the corner unit. Four comparison subsites are divided by a road; these subsites each consist of two units, one on each side of the road. The comparison subsite in Burnett County Forest (similar vegetation but in timber management) was burned once during 1994-2005, in 2000

(affecting all parts) during this study. Maximum distance separating comparison sites was $50.55 \mathrm{~km}$.

All of Muralt Bluff (Fig. 3) was managed with fire during 1977-1989 prior to our study (Wisconsin Department of Natural Resources unpublished data) and in 1990-2005 during our study. The refugium (about 3 ha) was last burned in spring 1991. A small area (about $1 \mathrm{ha}$ ) contiguous to it to the east was unburned during 1986-1999. Brush-cutting occurred in the refugium and other units. The comparison sites all had units never managed with fire throughout our study. Conservation management at our survey units in the Thomson complex (Fig. 4) has been hand-cutting of brush in the never-burned refugium (11 ha), and hand-cutting, mowing, and burning elsewhere. Hogback was private land with light cattle-grazing through 1997; as a preserve from 1998 on, it had brushcutting in some years and no fire in our survey area until half was burned in 2005 (other burning also occurred outside our survey area in brushy and more degraded areas). Buena Vista had a wide range of managements in scattered non-contiguous plots of about $8-48$ ha, with an average per year of $4 \%$ burned, $5 \%$ cattle grazed, and $5 \%$ hayed per year, with smaller amounts per year mechanically brush-cut, disked (lightly plowed), or planted to wildlife crops. Some units had a long history of no management or a single management type, while others had a mixture of managements.

\section{Analysis}

Analysis was done with ABstat 7.20 software (1994, Anderson-Bell Corp., Parker, Colorado), with statistical significance set at $P<0.05$. Since significant results 


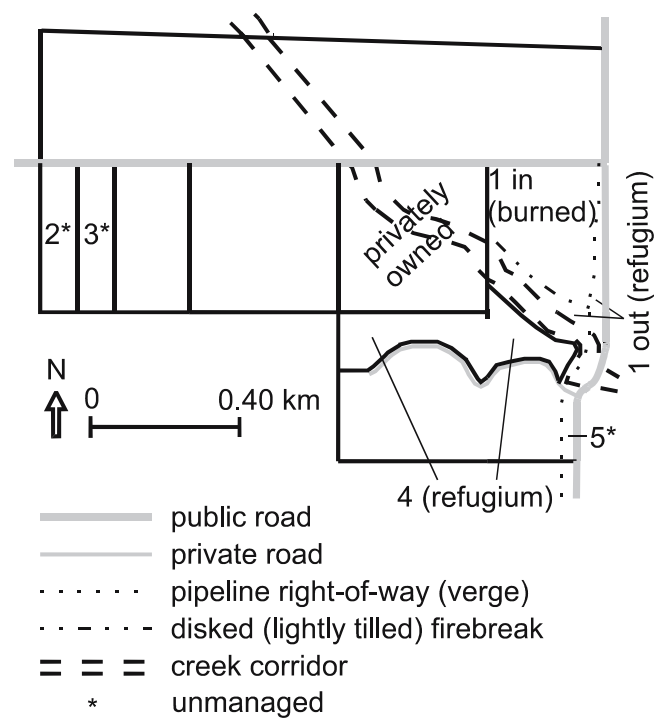

Fig. 2 Map of Bauer-Brockway pine barren. Unit 1 out (refugium) is bounded by public road, pipeline right-of-way, disked firebreak, and creek corridor

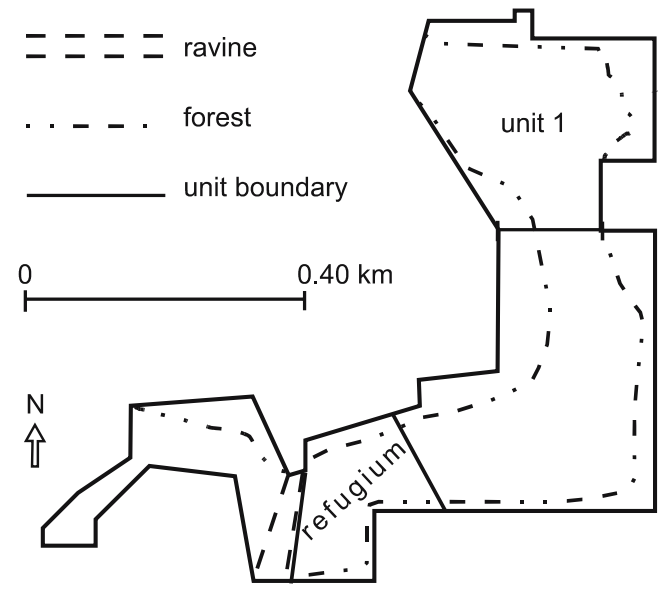

Fig. 3 Map of Muralt Bluff Prairie

occurred much more frequently than expected due to Type I statistical errors, we did not lower the $P$ value further, as more Type II errors would then be created than Type I errors eliminated. Non-significant values $(0.05<P<0.10$ and $P>0.10)$ are also presented because non-significant tests that have the same sign as related significant tests indicate more consistency of pattern in a dataset than if the sign is opposite, and to show patterns of greater or lesser significance. All correlations were done with the Spearman rank correlation. To test for significant differences in indices, we used the Wilcoxon signed ranks test for paired values (refugium versus comparison in the same years) and the Mann-Whitney $U$ test for $>2$ variates in a test if $N>5$ per variate (to afford adequate statistical power

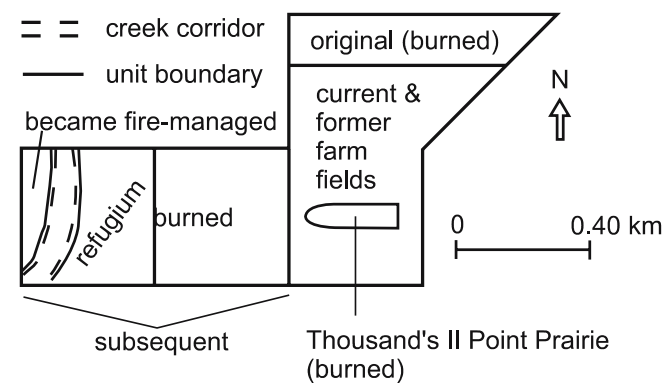

Fig. 4 Map of Thomson complex, showing original and subsequent acquisitions of Thomson Prairie and Thousand's II Point Prairie. "Became fire-managed" = never-burned 1992-1994; then became fire-managed (burned twice during 1995-2005)

for this test). We analyzed all specialist species as defined in Swengel (1998b), not just legally listed species, if found in analyzable numbers in both the refugium and comparisons.

A fire year-class of 0 signifies the unit was burned since the last growing season; management fires typically occurred in the cool season (spring or fall), not summer. Thus, a fire after summer 1987 and before summer 1988 is said here to have burned in 1988. At Crex Meadows, during 1991-97, the refugium (last burned in 1988) went from fire year-class 3 to 9 . At the comparison subsites here during this study, the maximum fire year-class was 8 (once each at two units). All comparison subsites experienced fire in one or both units during both 1991-97 and 1998-2005. We set these time periods to have equal samples of years but also to distinguish when the refugium was clearly beyond the fire return interval otherwise practiced at the site. For these reasons, we used the same periods for Muralt Bluff (refugium last burned in 1991). For BauerBrockway, we used 1992-2001 for the earlier period and 2002-2005 for the later period (after the management fire occurred). We used the Chi Square Goodness of Fit test to compare relative distributions of all analyzable specialist species in the refugium and comparison units, using the observed distribution in the earlier period to calculate the "expected" distribution in the later period. We required that the species be recorded in at least 2 years in each period for this analysis. At Crex Meadows and Muralt Bluff, we calculated the mean fire year-class per year for all monitoring units, and all units except the refugium. We correlated these mean fire year-classes versus year, and tested for significant differences in these year-classes between the earlier (1991-97) and later (1998-2005) periods with the Mann-Whitney U test.

We analyzed trends (correlation of indices with year), both with each year's peak indices and a 3-year 
running average of these indices, to damp out short-term variability from fluctuations to make longer term trends more apparent. We compared trends at the sites with refugia to trends of mean indices at the comparisons. We correlated population indices between the refugium and comparisons, and tested for significant differences in these indices.

For Karner blues at Crex Meadows, we also examined differences in indices in both periods by various management types because we were able to control for caterpillar food plant abundance (by analyzing only units with the same rating as for the refugium) and had several distinct management types surveyed long-term. For Karner blue more so than for regal fritillary (Swengel 1997) and frosted elfin (Swengel 1996b), covariance was strong between adult indices and caterpillar food plant abundance (Swengel and Swengel 1996). In this analysis, the earlier period was 1992-1997 because in 1991, some transects were not divided into the management unit boundaries used in later years, and 1996 had to be omitted due to missing values in some units.

\section{Results}

At Crex Meadows and Bauer-Brockway, all significant changes in specialist butterfly numbers skewed toward relatively higher proportions in the refugium versus comparison units in the later period than expected from our observations in the earlier period (Table 2). At Crex Meadows, 4/8 tests (4/6 species) were significantly higher in the refugium (last burned in 1988) in the later period than in the comparisons (fire-managed in both periods) (Table 2). Summer Karner blue indices in the refugium started lower than the mean for the comparisons, then rose higher than this mean but remained close to it (Fig. 5). At Bauer-Brockway, frosted elfins were significantly over-represented in the never-firemanaged refugium and absent in the rest of the unit after it had its first management fire (Fig. 6, Table 2). In addition, Olympia marble (Euchloe olympia); gorgone checkerspot (Chlosyne gorgone); Persius duskywing (Erynnis persius); and Leonard's (Hesperia leonardus), cobweb (Hesperia metea), and dusted (Atrytonopsis hianna) skippers occurred in all survey units here in the earlier and later periods, except cobweb skipper was unrecorded in unit 5 later. Phlox moth occurred in unit 2 (1 earlier, 0 later), 4 (29 earlier, 4 later), and 5 ( 3 earlier, 0 later), the only units with this moth's caterpillar food plant. Only Olympia marble and Persius duskywing occurred regularly in many comparison sites; at no comparison did we record all specialists found at Bauer-Brockway.
At both these sites, all specialist trends (correlations of indices with year) were positive in the refugium, and were usually more favorable than, or otherwise similar to, trends in comparisons (Table 3). At Crex Meadows, all summer Karner blue trends were positive (Table 3), and indices significantly covaried between the refugium and comparisons (Table 4). But trends were far from significant except for the refugium 3-year running average (Table 3 ). The summer mottled duskywing (Erynnis martialis) trend was positive and significant in the refugium (Table 3), but negative and non-significant in the comparisons. Mottled duskywing indices negatively correlated between the refugium and comparisons, but far from significantly (Table 4). For phlox moth trends, $r=+0.195$ for the refugium $(N=0$ individuals in 1994 and 6 during 1998-2005) versus -0.120 for the mean of three comparisons $(N=33$ individuals $)$ for 8 survey years during 1994-2005 $(P>0.10)$, and +0.259 in the refugium versus +0.286 (mean of five comparisons) for 7 survey years during 1994-2004 $(P>0.10)$. Three $(25 \%)$ of 12 frosted elfin trends were significant (Table 5). Except for unit 1 inside (firemanaged), Bauer-Brockway units had positive trends (significantly so in the refugium 3-year average) while the mean of the comparisons had negative trends. Although $77 \%$ of pair-wise correlations of the localities in Fig. 6 were positive (testing both annual indices and 3 -year running averages), only slightly more tests $(2 / 26$, or $8 \%)$ had $P<0.05$ than the $5 \%$ expected due to chance; unit 1 inside (fire-managed) versus outside (never-fire-managed refugium) had negative nonsignificant $(P<0.10)$ correlations. For summer Karner blue indices (Fig. 7), trends were positive but not significant in unit 1 (part never-fire-managed refugium; part fire-managed) for 1999-2005 (Table 5) and the longer series of years (1992, 1994-95, 1999-2005: $r=+0.178, N=10, P>0.10)$. Trends were similar for our other Bauer-Brockway units, but negative and non-significant for the mean of comparisons.

By contrast, at Muralt Bluff, regal fritillaries were significantly more skewed (as a proportion of total individuals) to the refugium (last burned in 1991) during the earlier period (Table 2). However, indices were significantly higher in this refugium in the later than earlier period, and in the refugium throughout this study than in the other units (fire-managed in both periods) at this site (Table 6). In the Thomson complex (a comparison site), we cannot compare earlier (neverburned) to later (burned) due to lack of data from firemanaged areas from before burning started. However, regal fritillaries were also significantly more abundant in the never-burned refugium there than elsewhere in the site (Table 6) and were less concentrated in this 
Table 2 Chi-square goodness-of-fit tests for differences in proportion of specialist butterflies recorded in refugium and comparison units in the later period (expected values based on observations in earlier period)

\begin{tabular}{|c|c|c|c|c|c|}
\hline 1991-1997 & $\begin{array}{l}\text { Crex Meadows }{ }^{\mathrm{a}} \\
\text { Karner blue }\end{array}$ & Gorgone checkerspot & Mottled duskywing & & \\
\hline Refugium & $28(11 \%)$ & $6(46 \%)$ & $0(0 \%)$ & & \\
\hline Comparison & $225(89 \%)$ & $7(54 \%)$ & $25(100 \%)$ & & \\
\hline \multicolumn{6}{|l|}{ 1998-2005 Observed } \\
\hline Refugium & $67(14.5 \%)$ & $3(43 \%)$ & $3(15 \%)$ & & \\
\hline Comparison & $395(85.5 \%)$ & $4(57 \%)$ & $17(85 \%)$ & & \\
\hline \multicolumn{6}{|l|}{ 1998-2005 Expected } \\
\hline Refugium & 51 & 3 & 0 & & \\
\hline Comparison & 411 & 4 & 20 & & \\
\hline \multirow[t]{2}{*}{$P$ value } & $<0.05$ & $>0.10$ & $<0.00005$ & & \\
\hline & $\begin{array}{l}\text { Crex Meadows } \\
\text { Olympia marble }\end{array}$ & Gorgone checkerspot & Mottled duskywing & Persius duskywing & Dusted skipper \\
\hline \multicolumn{6}{|l|}{ 1994-1995 } \\
\hline Refugium & $1(4 \%)$ & $1(9 \%)$ & $1(25 \%)$ & $0(0 \%)$ & $5(19 \%)$ \\
\hline Comparison & $22(96 \%)$ & $10(91 \%)$ & $3(75 \%)$ & $12(100 \%)$ & $21(81 \%)$ \\
\hline \multicolumn{6}{|l|}{ 1999-2004 Observed } \\
\hline Refugium & $3(12 \%)$ & $17(47 \%)$ & $0(0 \%)$ & $1(12.5 \%)$ & $55(49 \%)$ \\
\hline Comparison & $23(88 \%)$ & $19(53 \%)$ & $10(100 \%)$ & $7(87.5 \%)$ & $57(51 \%)$ \\
\hline \multicolumn{6}{|l|}{ 1999-2004 Expected } \\
\hline Refugium & 1 & 3 & 2.5 & 0 & 22 \\
\hline Comparison & 25 & 33 & 7.5 & 8 & 90 \\
\hline Years found $1999-04$ & 3 & 2 & 3 & 2 & 3 \\
\hline \multirow[t]{3}{*}{$P$ value } & $>0.10$ & $<0.00005$ & $>0.10$ & $>0.10$ & $<0.00005$ \\
\hline & Muralt Bluff ${ }^{\mathrm{d}}$ & & Thomson $^{\mathrm{e}}$ & & \\
\hline & Regal fritillary & Ottoe skipper & Regal fritillary & & \\
\hline \multicolumn{6}{|l|}{ 1991-1997 } \\
\hline Refugium & $66(68 \%)$ & $5(7 \%)$ & $109(78 \%)$ & & \\
\hline Comparison & $31(32 \%)$ & $69(93 \%)$ & $30(22 \%)$ & & \\
\hline \multicolumn{6}{|l|}{ 1998-2005 Observed } \\
\hline Refugium & $178(55 \%)$ & 0 & $337(63 \%)$ & & \\
\hline Comparison & $144(45 \%)$ & 0 & $195(37 \%)$ & & \\
\hline \multicolumn{6}{|l|}{ 1998-2005 Expected } \\
\hline Refugium & 219 & - & 415 & & \\
\hline Comparison & 103 & - & 117 & & \\
\hline \multirow[t]{2}{*}{$P$ value } & $<0.00005$ & - & $<0.00005$ & & \\
\hline & $\begin{array}{l}\text { Bauer-Brockway unit } 1^{\mathrm{f}} \\
\text { Frosted Elfin }\end{array}$ & & & & \\
\hline \multicolumn{6}{|l|}{ 1992-2001 } \\
\hline Refugium & $5(42 \%)$ & & & & \\
\hline Comparison & $7(58 \%)$ & & & & \\
\hline \multicolumn{6}{|l|}{ 2002-2005 Observed } \\
\hline Refugium & $5(100 \%)$ & & & & \\
\hline Comparison & $0(0 \%)$ & & & & \\
\hline \multicolumn{6}{|l|}{ 2002-2005 Expected } \\
\hline Refugium & 2 & & & & \\
\hline Comparison & 3 & & & & \\
\hline$P$ value & $<0.05$ & & & & \\
\hline
\end{tabular}

a Refugium (last burned in 1988) is $11 \%(0.56 \mathrm{~km})$ of transect distance; the 10 comparison subsites (14 units) in summer surveys are $89 \%$ $(4.7 \mathrm{~km})$ of transect distance

${ }^{\mathrm{b}}$ Refugium (last burned in 1988 ) is $16 \%(0.56 \mathrm{~km})$ of transect distance; the seven comparison subsites (8 units) in spring surveys are $84 \%$ $(2.9 \mathrm{~km})$ of transect distance

${ }^{\mathrm{c}}$ Identified as species complex because field identification is not adequately reliable

${ }^{\mathrm{d}}$ Refugium (last burned in 1991) is $22 \%(0.68 \mathrm{~km})$ of the transect distance at Muralt Bluff (total length $3.1 \mathrm{~km}$ )

${ }^{\mathrm{e}}$ Refugium (never-burned) is $37 \%(0.60 \mathrm{~km})$ of the transect distance at subsequent acquisition (total length $1.65 \mathrm{~km}$ )

${ }^{\mathrm{f}}$ Refugium ("outside" the spring $\left.2002 \mathrm{burn}\right)$ is $60 \%(0.60 \mathrm{~km})$ of transect distance; the rest of the unit ("inside" the spring $\left.2002 \mathrm{burn}\right)$ is $40 \%$ 
Fig. 5 Karner blues/km per single summer survey at the refugium compared to the mean from 10 comparison subsites in fire management, as 3-year running averages, at Crex Meadows. CVs for annual means of the 10 comparison subsites averaged 112.7 per year, range 71.0 (2001) to 165.5 (1993)

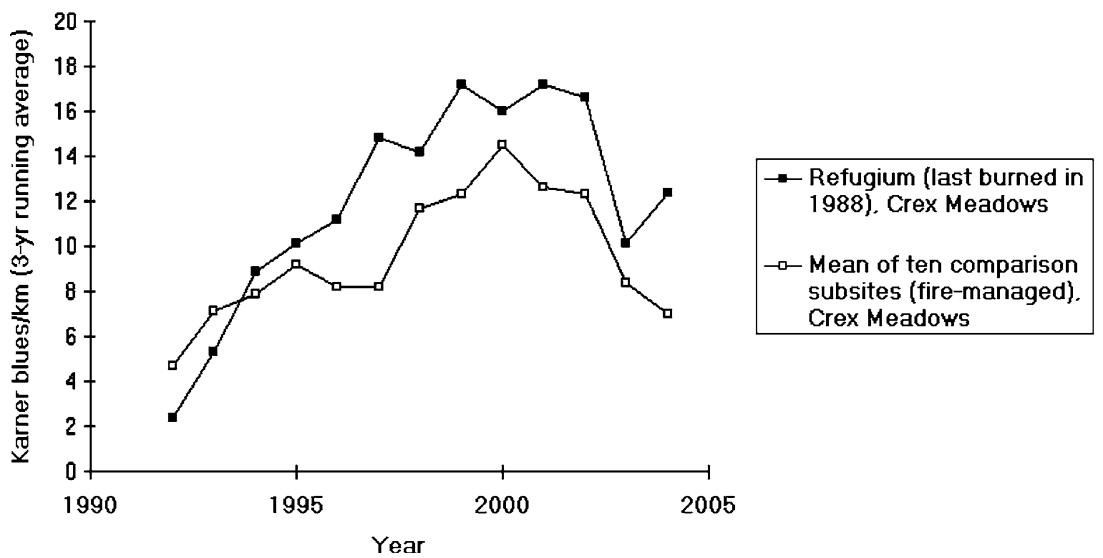

Fig. 6 Frosted elfins/km on peak survey/year in units of Bauer-Brockway, compared to mean of 11 comparison sites, as 3-year running averages. CVs for annual means of the 3 comparison units averaged 103.5 per year, range $0(1994,1996)$ to 173.2 (1992, 1997, 1998, 2002). CVs for annual means of the 11 comparison sites averaged 213.0 per year, range 95.2 (1994) to 331.7 (2005)

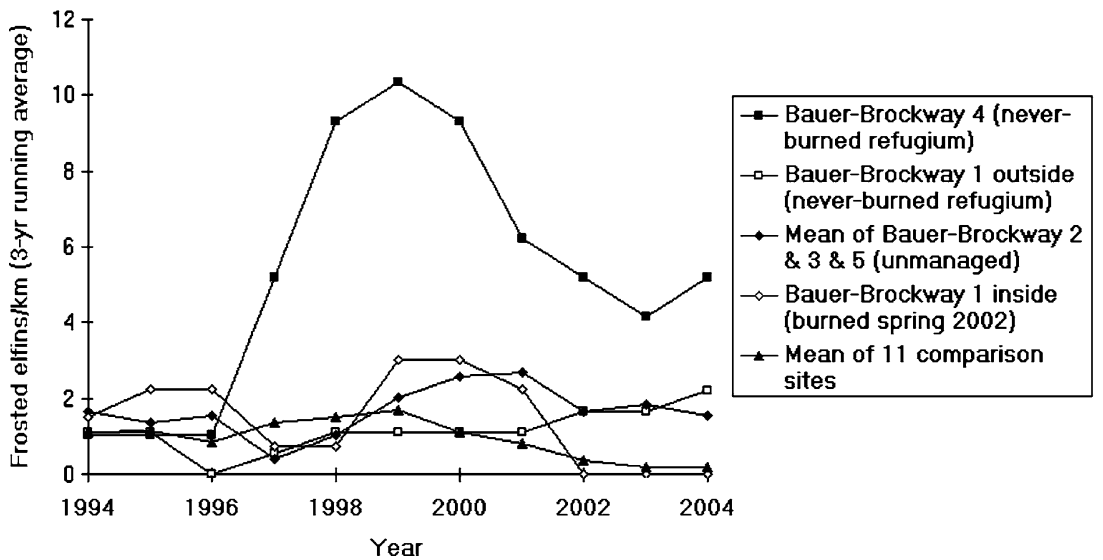

core area (the refugium) when indices were higher there, also in the later period (Table 2). Furthermore, at Muralt Bluff, in the earlier period, regal fritillary indices had the opposite trend as comparison sites (i.e. they correlated significantly yet negatively), but they covaried significantly in the later period (Fig. 8, Table 4). During the earlier period, regal fritillary indices at Muralt Bluff significantly declined, while the comparison sites had positive and primarily nonsignificant trends (Table 3). During the later period, Muralt Bluff had a significant positive regal fritillary trend; the other sites (which all had never-burned refugia during the entire study) continued to have positive trends, some significantly so. All 1992-2005 trends were positive, many significantly so.

At Muralt Bluff, regal fritillary indices covaried strongly between the refugium and other (fire-managed) units $(r=+0.841, N=15, P<0.01)$. Indices at Muralt Bluff and Oliver ( $<2 \mathrm{~km}$ away) correlated positively but not significantly: $r=+0.326, N=16$, or $r=+0.247, N=12$ when excluding 4 years $(1992,1997$, $2000,2005)$ of $100 \%$ burns of Oliver, $P>0.10$. We recorded regal fritillaries at Oliver only in 5 years (1991, 1993, 1994, 2002, 2004; total of 10 individuals; transect length $0.40 \mathrm{~km}$ ), although the site had regular sightings before our study (Borth 1992). In the Thomson complex (Fig. 4), indices in the never-burned refugium significantly covaried with indices from the unit to its west (never-burned until burned twice during 1995-2005) (Table 7); correlations were positive but non-significant with the fire-managed unit east of the refugium and with Thomson original acquisition (1.0 km away), but significant with Thousand's II. Except for the unit east of the refugium (which is closest to the refugium), the degree of correlation is in inverse order of distance separating the units. Thus, regal fritillary indices tended to covary most strongly at distances $<1 \mathrm{~km}$ apart.

The refugium at Muralt Bluff was not a core area for Ottoe skipper (Hesperia ottoe); only 7\% of individuals occurred there during 1991-97 although the refugium comprised $22 \%$ of the transect at this site (Table 2). We recorded no Ottoe skippers at Muralt Bluff during 1998-2005. Although the species occurred in all parts of our transect there, its core area was in our unit 1 (Fig. 3); during 1991-97, we recorded 47 individuals $(64 \%)$ there and this unit comprised only $21 \%$ of the transect in the site. While Ottoe skipper was significantly 
Table 3 Mean summer population indices and Spearman rank correlation (trend) of these indices with year

${ }^{a} N=15$ years for annual indices and $N=13$ years for 3 -year running averages of these indices, for the refugium and the 10 comparison subsites

b For annual indices, $N=7$ years for $1992-98$, $N=8$ years for $1998-2005$, and $N=14$ years for 1992 2005; for running averages, $N=5$ years, 6 years, and 12 years, respectively. Since data from 1991 were unavailable for some sites, correlations were done for 1992-98 rather than 1992-97, to increase sample size

\begin{tabular}{|c|c|c|c|c|c|}
\hline & \multirow[t]{2}{*}{ Mean index } & \multicolumn{2}{|c|}{ Annual index } & \multicolumn{2}{|c|}{ Three-year running average } \\
\hline & & $r$ & $P$ & $r$ & $P$ \\
\hline \multicolumn{6}{|l|}{ Crex Meadows 1991-2005 } \\
\hline \multicolumn{6}{|c|}{ Karner blue } \\
\hline All subsites & 9.0 & +0.196 & $>0.10$ & +0.291 & $>0.10$ \\
\hline Refugium & 11.2 & +0.413 & $<0.10$ & +0.616 & $<0.05$ \\
\hline Comparison subsites & 9.1 & +0.207 & $>0.10$ & +0.451 & $>0.10$ \\
\hline \multicolumn{6}{|l|}{ Mottled duskywing } \\
\hline All subsites & 0.6 & -0.215 & $>0.10$ & -0.166 & $>0.10$ \\
\hline Refugium & 0.4 & +0.286 & $>0.10$ & +0.855 & $<0.01$ \\
\hline Comparison subsites & 0.7 & -0.220 & $>0.10$ & -0.148 & $>0.10$ \\
\hline \multicolumn{6}{|l|}{ Regal fritillary ${ }^{\mathrm{b}}$} \\
\hline \multicolumn{6}{|l|}{$1992-98$} \\
\hline Muralt Bluff & 4.8 & -0.857 & $<0.05$ & -1.000 & $<0.01$ \\
\hline Hogback & 23.6 & +0.430 & $>0.10$ & +0.600 & $>0.10$ \\
\hline Thomson complex & 8.6 & +0.464 & $>0.10$ & +0.900 & $<0.05$ \\
\hline \multicolumn{6}{|l|}{ 1998-2005 ו } \\
\hline Muralt Bluff & 12.7 & +0.810 & $<0.05$ & +1.000 & $<0.01$ \\
\hline Hogback & 50.9 & +0.310 & $>0.10$ & +0.886 & $<0.05$ \\
\hline Thomson complex & 20.5 & +0.762 & $<0.05$ & +0.943 & $<0.01$ \\
\hline Buena Vista & 14.0 & +0.405 & $>0.10$ & +0.829 & $<0.05$ \\
\hline \multicolumn{6}{|l|}{$1992-2005$} \\
\hline Muralt Bluff & 9.7 & +0.512 & $<0.10$ & +0.524 & $<0.10$ \\
\hline Hogback & 37.0 & +0.793 & $<0.001$ & +0.944 & $<0.001$ \\
\hline Thomson complex & 15.0 & +0.785 & $<0.001$ & +0.965 & $<0.001$ \\
\hline \multicolumn{6}{|l|}{ Ottoe skipper ${ }^{\mathrm{b}}$} \\
\hline \multicolumn{6}{|l|}{$1992-98$} \\
\hline Muralt Bluff & 1.8 & -0.811 & $<0.05$ & -0.975 & $<0.01$ \\
\hline Hogback & 0.6 & -0.045 & $>0.10$ & -0.632 & $>0.10$ \\
\hline \multicolumn{6}{|l|}{$1998-2005$} \\
\hline Muralt Bluff & 0.0 & & & & \\
\hline Hogback & 0.4 & -0.300 & $>0.10$ & -0.471 & $>0.10$ \\
\hline \multicolumn{6}{|l|}{ 1992-2005 } \\
\hline Muralt Bluff & 0.9 & -0.797 & $<0.001$ & -0.935 & $<0.001$ \\
\hline Hogback & 0.5 & -0.456 & $>0.10$ & -0.851 & $<0.01$ \\
\hline
\end{tabular}

Table 4 Spearman rank correlation of indices in the refugium versus mean indices from comparison (sub)sites

\begin{tabular}{|c|c|c|c|c|c|c|}
\hline & \multicolumn{3}{|c|}{ Annual index } & \multicolumn{3}{|c|}{ Three-year running average } \\
\hline & $N$ & $r$ & $P$ & $N$ & $r$ & $P$ \\
\hline \multicolumn{7}{|l|}{ Crex Meadows } \\
\hline Karner blue $^{\mathrm{a}}$ & 15 & +0.537 & $<0.05$ & 13 & +0.795 & $<0.01$ \\
\hline Mottled duskywing ${ }^{\mathrm{a}}$ & 15 & -0.121 & $>0.10$ & 13 & -0.391 & $>0.10$ \\
\hline \multicolumn{7}{|l|}{ Muralt Bluff } \\
\hline \multicolumn{7}{|l|}{ Regal fritillary ${ }^{\mathrm{b}}$} \\
\hline $1992-1998^{\mathrm{c}}$ & 7 & -0.786 & $<0.05$ & 5 & -0.700 & $>0.10$ \\
\hline 1998-2005 & 8 & +0.714 & $<0.05$ & 6 & +0.943 & $<0.01$ \\
\hline 1992-2005 & 14 & +0.451 & $>0.10$ & 12 & +0.497 & $<0.10$ \\
\hline \multicolumn{7}{|l|}{ Regal fritillary ${ }^{\mathrm{d}}$} \\
\hline 1998-2005 & 8 & +0.762 & $<0.05$ & 6 & +0.943 & $<0.01$ \\
\hline
\end{tabular}

a Crex Meadows (summer): Refugium (last burned in 1988) versus 10 comparison subsites

b Muralt Bluff (contains a refugium last burned in 1991) versus mean from 2 comparison sites (which always had never-burned refugia): Thomson complex (4.20 km transect route; 919 individuals recorded) and Hogback Prairie (2.45 km transect route; 1270 individuals)

c Since data from 1991 were unavailable for some sites, correlations were done for 1992-98 rather than 1992-97, to increase sample size

${ }^{\mathrm{d}}$ Same as ${ }^{\mathrm{b}}$ but mean also includes Buena Vista Grassland (9.6 km total transect in 12 locations; 1500 individuals recorded) 
Table 5 Mean population indices in units of Bauer-Brockway, and the mean of other monitoring sites, and Spearman rank correlation (trend) of these indices with year

\begin{tabular}{|c|c|c|c|c|c|c|}
\hline & \multirow[t]{2}{*}{ Mean } & \multirow[t]{2}{*}{$\mathrm{CV}$} & \multicolumn{2}{|c|}{ Annual index } & \multicolumn{2}{|c|}{ Three-year average } \\
\hline & & & $r$ & $P$ & $r$ & $P$ \\
\hline \multicolumn{7}{|l|}{ Frosted elfin ${ }^{\mathrm{a}}$} \\
\hline \multicolumn{7}{|l|}{ Bauer-Brockway } \\
\hline 1 & 1.25 & 65.4 & +0.144 & $>0.10$ & +0.023 & $>0.10$ \\
\hline 1 inside (burned 2002) & 1.22 & 179.7 & -0.245 & $>0.10$ & -0.456 & $>0.10$ \\
\hline 1 outside $\left(\mathrm{NFM}^{\mathrm{b}}\right.$ refugium $)$ & 1.27 & 94.3 & +0.484 & $<0.10$ & +0.755 & $<0.01$ \\
\hline $4\left(\mathrm{NFM}^{\mathrm{b}}\right.$ refugium $)$ & 5.02 & 85.8 & +0.516 & $<0.10$ & +0.408 & $>0.10$ \\
\hline $2 \& 3 \& 5$ (unmanaged) & 1.60 & 83.8 & +0.306 & $>0.10$ & +0.400 & $>0.10$ \\
\hline 11 comparison sites & 0.87 & 87.0 & -0.586 & $<0.05$ & -0.670 & $<0.05$ \\
\hline \multicolumn{7}{|l|}{ Karner blue } \\
\hline \multicolumn{7}{|l|}{ Bauer-Brockway } \\
\hline 1 (part NFM ${ }^{\mathrm{b}}$ ref. \& part burned) & 9.7 & 99.0 & +0.631 & $>0.10$ & +0.400 & $>0.10$ \\
\hline $4\left(\mathrm{NFM}^{\mathrm{b}}\right.$ refugium $)$ & 49.7 & 47.4 & +0.607 & $>0.10$ & +0.200 & $>0.10$ \\
\hline 5 (unmanaged) & 70.7 & 56.1 & +0.144 & $>0.10$ & 0.000 & $>0.10$ \\
\hline 12 comparison sites & 29.3 & 60.4 & -0.631 & $>0.10$ & -0.70 & $>0.10$ \\
\hline
\end{tabular}

${ }^{a} N=13$ years for annual indices, for 1992 and 1994-2005 and $N=11$ years for 3-year running averages, with the first average for 1992, 1994, and 1995

b NFM = never-fire-managed

c $N=7$ years for annual indices during summer 1999-2005 and $N=5$ years for 3-year running averages of these indices

Fig. 7 Karner blues/km on peak summer survey/year in units of Bauer-Brockway, compared to mean of seven and 12 comparison sites, as 3 -year running averages. CVs for annual means of the 12 comparison units averaged 113.7 per year, range 76.5 (2000) to 163.9 (2004). CVs for annual means of the 7 comparison units averaged 87.1 per year, range 16.6 (1997) to 160.8 (2004)

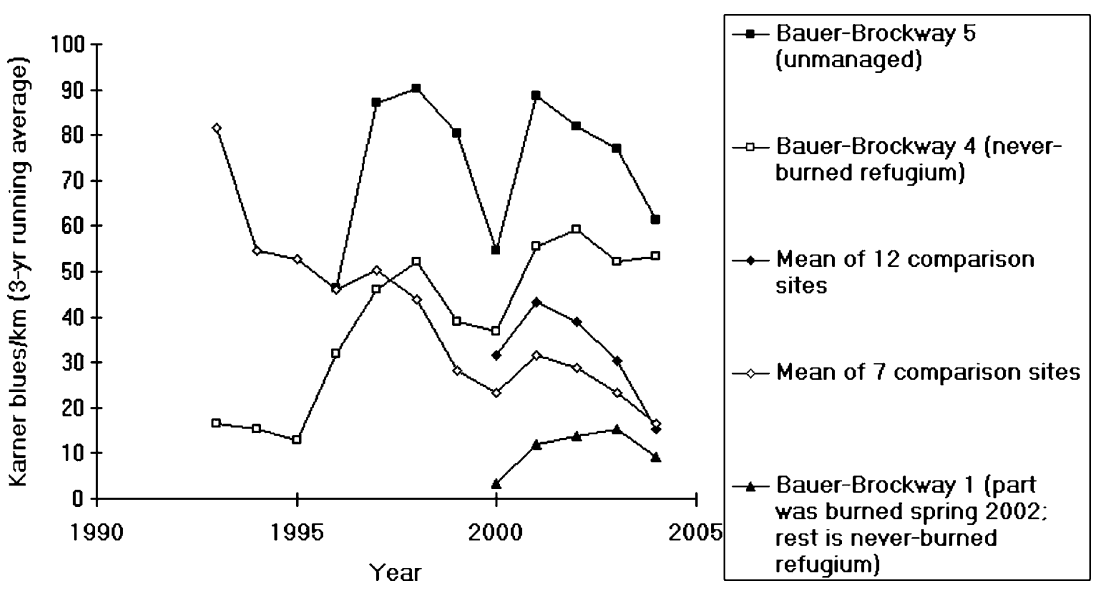

fire year-class averaged $<5$. When including the refugium, mean fire year-class of all surveyed units increased significantly (i.e. fire return intervals were higher) in more recent years during the entire study period at both sites (Table 8: correlation with year). Although at Crex Meadows this increase was so small that the year-classes in the earlier period did not significantly differ from those in the later period, the means in the later period were significantly higher than those in the earlier period at Muralt Bluff (Table 8: Mann-Whitney U test). Thus, at both sites, the greater influence on fire return interval in our survey units was the protracted lack of fire in the refugium, not an increase in interval in the fire-managed units. 
Table 6 Mean regal fritillary population indices in refugium (last burned in 1991) and other units (fire-managed) at Muralt Bluff and Thomson complex

\begin{tabular}{lrr}
\hline & Mean & CV \\
\hline Muralt Bluff $^{\text {a }}$ & & \\
1991-97 & & \\
$\quad$ Refugium (last burned in 1991) & $15.9 \mathrm{~A}$ & 48.9 \\
$\quad$ Other units (fire-managed) & $2.7 \mathrm{~B}$ & 95.4 \\
1998-2005 & & \\
$\quad$ Refugium (last burned in 1991) & $32.5 \mathrm{~A}$ & 79.2 \\
$\quad$ Other units (fire-managed) & $7.5 \mathrm{~B}$ & 91.2 \\
1991-2005 & & \\
$\quad$ Refugium (last burned in 1991) & $24.8 \mathrm{~A}$ & 83.9 \\
$\quad$ Other units (fire-managed) & $5.2 \mathrm{~B}$ & 109.0 \\
Thomson complex, 1992-2005 & & \\
Thomson subsequent acquisition & & \\
$\quad$ Refugium (never burned) & $53.5 \mathrm{~A}$ & 61.8 \\
$\quad$ Became fire-managed & \\
$\quad$ Fire-managed & $34.2 \mathrm{~B}$ & 120.8 \\
Thousand's II (fire-managed) & $7.2 \mathrm{C}$ & 143.3 \\
Thomson original (fire-managed) $^{\mathrm{c}}$ & $11.1 \mathrm{BC}$ & 126.5 \\
& $4.6 \mathrm{C}$ & 93.9 \\
\end{tabular}

${ }^{a}$ Within each time period at Muralt Bluff, means not sharing any letters are significantly different (Wilcoxon signed ranks test two-tailed $P<0.05$ )

b Means at Thomson complex not sharing any letters are significantly different (Mann-Whitney $\mathrm{U}$ test two-tailed $P<0.05)$

c Never-burned 1992-1994; then became fire-managed (burned twice during 1995-2005)

At Crex Meadows, mechanical cutting had significantly higher summer Karner blue indices than the three management types with a fire component (Table 9). The refugium (last burned in 1988) did not significantly differ from the other fire management types but averaged a bit higher indices. Although all management types had high CVs, mechanical cutting and the refugium had the lowest CVs. Likewise, at Bauer-Brockway, the firemanaged area had the highest $\mathrm{CV}$ for both frosted elfin and summer Karner blue indices (Table 5). Regal fritillary indices in the refugium (last burned in 1991) at
Muralt Bluff and the never-burned refugium at the Thomson complex had lower CVs than in other (firemanaged) units at the same site (Table 6).

\section{Discussion}

Due to the numerous statistical tests in this paper, greater confidence should be placed in patterns that recurred frequently with significance or consistent nonsignificance. Furthermore, significant regional trends reported here may be due to climatic fluctuation rather than management and/or vegetation changes. These analyses did not investigate factors associated with regional trends. Instead, we examined whether a refugium site had trends and patterns deviating from the regional mean, attributable to differences in management between the refugium and comparison sites.

All significant changes in specialist butterfly numbers skewed toward relatively higher abundance in the refugium (last burned in 1988) during the later period at Crex Meadows (Table 2) and in the neverfire-managed refugium at Bauer-Brockway after the rest of the unit had its first management fire (Table 2). At these sites, tests of trend (correlation of indices with year) were positive in the refugia while comparisons usually had less favorable trends (Tables 3, 4); in no case were trends at the refugium less favorable than at the comparisons. By contrast, at Muralt Bluff (the smallest refugium site), regal fritillaries were significantly more skewed to the refugium (last burned in 1991) during the earlier period (Table 2), but indices were significantly higher in the refugium in the later than earlier period, and in the refugium than in the other units (fire-managed in both periods) here (Table 6). In the earlier period, the population trend for the entire site was significantly negative and opposite of comparison sites, which always had
Fig. 8 Regal fritillaries/km on peak survey/year at Muralt Bluff compared to the mean from two or three comparison sites (which always had neverburned refugia), as 3-year running averages. CVs for annual means of the two comparison sites averaged 44.5 per year, range 4.8 (1995) to 90.2 (1993). CVs for annual means of the 3 comparison sites averaged 57.5 per year, range 18.5 (2005) to 75.6 (2001)

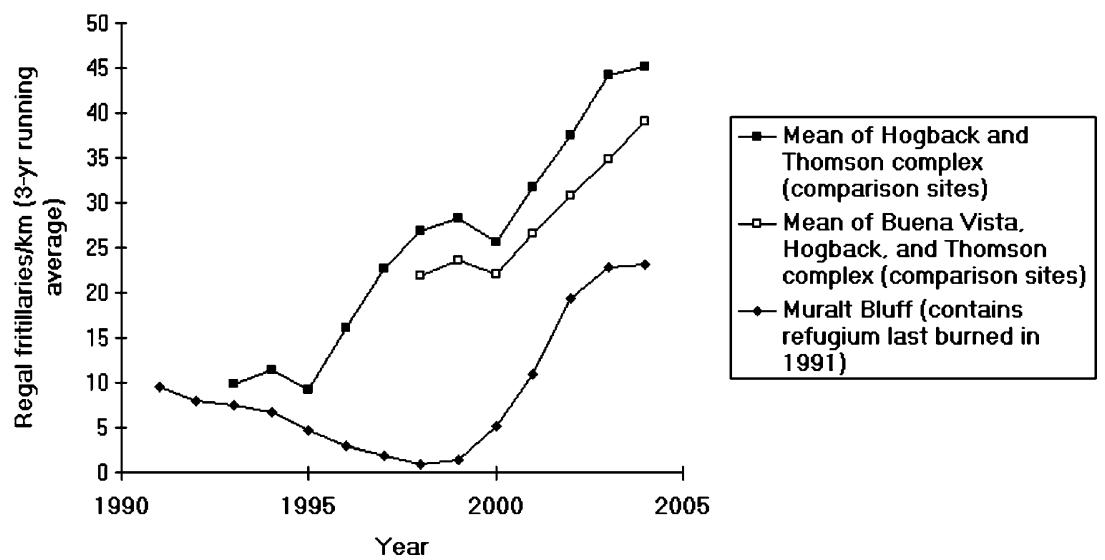


Table 7 Spearman rank correlation of regal fritillary indices in Thomson subsequent acquisition refugium (never burned) with indices from comparison units in Thomson complex, 1992-2005

\begin{tabular}{|c|c|c|c|c|c|c|}
\hline & \multicolumn{3}{|c|}{ Annual index } & \multicolumn{3}{|c|}{ Three-year running average } \\
\hline & $N$ & $r$ & $P$ & $N$ & $r$ & $P$ \\
\hline \multicolumn{7}{|l|}{ Thomson subsequent acquisition } \\
\hline Became fire-managed $^{\mathrm{a}}$ & 14 & +0.781 & $<0.01$ & 12 & +0.860 & $<0.01$ \\
\hline Fire-managed & 14 & +0.455 & $>0.10$ & 12 & +0.483 & $>0.10$ \\
\hline Thousand's II (fire-managed) & 14 & +0.640 & $<0.05$ & 12 & +0.657 & $<0.05$ \\
\hline Thomson original (fire-managed) & 14 & +0.317 & $>0.10$ & 12 & +0.404 & $>0.10$ \\
\hline All of the above units & 14 & +0.689 & $<0.01$ & 12 & +0.690 & $<0.05$ \\
\hline
\end{tabular}

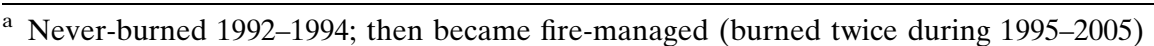

never-burned refugia; in the later period, the trend at Muralt Bluff became significantly positive and comparable to trends at comparisons (Table 3). At both Crex Meadows and Muralt Bluff, the one refugium significantly increased the fire return interval of our sampling units (Table 8: significant positive trend for all units during 1991-2005), even though the other units retained a relatively similar (non-significantly changing) fire regime throughout the study (Table 8: non-significant trends for all units except refugium), within the range of typical rotations (up to 5 or 6 year cycles, pers. obs.).

In this study, permanent non-fire refugia (with unintensive alternative managements such as mowing and brush-cutting) within fire-managed sites had numerous benefits for specialized Lepidoptera and no

Table 8 Mean fire year-class, and Spearman rank correlation (trend) of mean year-class and year, by site

\begin{tabular}{|c|c|c|c|c|c|}
\hline & $N$ & $\operatorname{Mean}^{\mathrm{a}}$ & $\mathrm{CV}$ & $r$ & $P$ \\
\hline \multicolumn{6}{|c|}{ Crex Meadows Wildlife Area } \\
\hline \multicolumn{6}{|c|}{ All units (including refugium) } \\
\hline 1991-97 & 7 & $2.5 \mathrm{~A}^{\mathrm{b}}$ & 31.7 & +0.126 & $>0.10$ \\
\hline $1998-2005$ & 8 & $3.7 \mathrm{~A}^{\mathrm{b}}$ & 24.3 & +0.333 & $>0.10$ \\
\hline 1991-2005 & 15 & 3.2 & 32.2 & +0.527 & $<0.05$ \\
\hline \multicolumn{6}{|c|}{ All units except refugium } \\
\hline 1991-97 & 7 & $2.2 \mathrm{~A}$ & 41.5 & -0.214 & $>0.10$ \\
\hline 1998-2005 & 8 & $2.9 \mathrm{~A}$ & 32.3 & +0.132 & $>0.10$ \\
\hline 1991-2005 & 15 & 2.6 & 37.1 & +0.266 & $>0.10$ \\
\hline \multicolumn{6}{|c|}{ Muralt Bluff } \\
\hline \multicolumn{6}{|c|}{ All units (including refugium) } \\
\hline 1991-97 & $7^{\circ}$ & $3.1 \mathrm{~A}$ & 34.3 & +0.929 & $<0.01$ \\
\hline $1998-2005$ & 8 & $5.4 \mathrm{~B}$ & 11.7 & -0.488 & $>0.10$ \\
\hline 1991-2005 & 15 & 4.3 & 33.1 & +0.746 & $<0.01$ \\
\hline \multicolumn{6}{|c|}{ All units except refugium } \\
\hline 1991-97 & 7 & $3.1 \mathrm{~A}^{\mathrm{b}}$ & 26.8 & +0.929 & $<0.01$ \\
\hline 1998-2005 & 8 & $4.2 \mathrm{~A}^{\mathrm{b}}$ & 25.0 & -0.762 & $<0.05$ \\
\hline 1991-2005 & 15 & 3.7 & 29.1 & +0.375 & $>0.10$ \\
\hline
\end{tabular}

${ }^{a}$ Within site and group of units, means for the earlier and later periods not sharing any letters are significantly different (MannWhitney U test two-tailed $P<0.05$ )

${ }^{\text {b }} P<0.10$ detectable negative outcomes. Other studies of specialist butterflies have advocated patchy fires that leave unburned refugia both within the burn perimeter and nearby (Panzer 2002, 2003), with an emphasis on refugia in the densest part of the butterfly population (McCabe 1981; Schweitzer 1994; New et al. 2000). At Indiana Dunes National Lakeshore, an unburned refugium densely occupied by Karner blues within a burn unit had $50 \%$ as many Karner blues as adjacent sections within the unit before burning but $200 \%$ as many after the burn (Kwilosz and Knutson 1999), a four-fold better trend for the refugium than burned areas.

$\mathrm{CVs}$ were higher for indices in units with current or more recent fire management (Tables 5, 9). Butterflies often have high variability, apparent from the relatively high CVs in the non-fire managements as well. For example, the Karner blue has large fluctuations in abundance among broods (Swengel and Swengel 1996, 2005; Knutson et al. 1999). Lower CVs are valuable for conservation because extremely low years (and thus extirpation) are less likely. Higher CVs, especially in small sites like Muralt Bluff, would make sites more vulnerable to local extirpation than expected in lowabundance years (cf. Pollard and Yates 1992) if not for the stabilizing effect of refugia in core areas.

The strong covariance of indices between the refugium and other units within Muralt Bluff (see Results) and Thomson (Table 7) suggest that the refugium was "exporting" regal fritillaries to the rest of the site. In years of low numbers, these populations appeared to contract somewhat into the core and decline more in outlying units (cf. Tables 2, 6). Regal fritillary indices had stronger covariances within a site at both Muralt Bluff (see Results) and Thomson subsequent acquisition (Table 7) than between close but non-adjoining sites 1-2 km away: Muralt Bluff versus Oliver (see Results) and Thomson original versus subsequent acquisitions (Table 7). Thus, establishing the refugium in the core for regal fritillary benefited the species in the site as a whole. Conversely, fire management of this 
Table 9 Mean summer population index for the Karner blue at Crex Meadows, by different management groups, for all units surveyed each year with lupine rated common

\begin{tabular}{|c|c|c|c|c|c|}
\hline & \multirow[t]{2}{*}{$N$ units } & \multicolumn{2}{|c|}{ 1992-95 and 1997} & \multicolumn{2}{|l|}{$1998-2005$} \\
\hline & & Mean index ${ }^{a}$ & $\mathrm{CV}$ & Mean index ${ }^{\mathrm{a}}$ & $\mathrm{CV}$ \\
\hline Mechanical cutting & 1 & 31.5 & 97.0 & $28.0 \mathrm{~A}$ & 62.7 \\
\hline Fire+cutting & 3 & 7.9 & 103.6 & $10.4 \mathrm{~B}$ & 80.4 \\
\hline Fire & 1 & 9.3 & 137.5 & $10.8 \mathrm{~B}$ & 175.2 \\
\hline Refugium (former fire) & 1 & 11.1 & 73.8 & $14.2 \mathrm{AB}$ & 60.1 \\
\hline Mean, all types & 6 & 12.6 & 130.0 & 14.0 & 97.2 \\
\hline Mean, three fire types & 5 & 8.8 & 100.9 & 11.3 & 97.9 \\
\hline
\end{tabular}

${ }^{a}$ Within time period, means not sharing any letters are significantly different (Mann-Whitney $\mathrm{U}$ test two-tailed $P<0.05$ for $1998-$ $2005, N=8$ years; the earlier period had an inadequate sample of years for this test)

core (the Muralt Bluff refugium was last burned in 1991) was unfavorable for the entire population (Table 3: significant decline in earlier period). A refugium needs to be relatively close to fire-managed habitat for the species to obtain significant conservation benefit in these fire-managed areas.

Selecting proper refugia based on previous surveys is essential (Sands and New 2002), as many specialized Lepidoptera and other insects live in small patches too isolated for the species to recolonize should it become extirpated (Panzer 1988; Orwig 1992). Even small refugia ( 3 ha at Muralt Bluff, plus 1 contiguous ha unburned during 1986-1999) are valuable to rare Lepidoptera, but their location should be carefully placed to include core habitat based on surveys (Kwilosz and Knutson 1999; New et al. 2000). The species deliberately targeted by the refugia in our study benefited from them, but Ottoe skipper at Muralt Bluff did not benefit from the small refugium (Tables 2, 3: significant decline and absence), which was not placed in a core area for this species. Likewise, haphazardly placed clearcut refugia did not duplicate the benefits of long-term unburned fire residuals for forest insects (Gandhi et al. 2003). At small sites (e.g., Muralt Bluff, Table 1), it may be necessary to select more than one unit as refugia to encompass adequate core habitat for multiple specialists. By contrast, at Crex Meadows and Bauer-Brockway, the refugia supported many specialists (Table 2 and Results), and all analyzable species had stable or positive trends, sometimes significantly so (Tables 3,5). At these large sites (Table 1), there was more choice in selecting larger refugia (14 and $4+$ 15 ha, respectively) serving the needs of multiple specialists and readily excluded from fire management. Multi-year surveys are necessary to determine core habitat and areas of higher specialist species richness.

Permanent non-fire refugia are valuable to many other groups of specialized organisms, since some may be extirpated by fires (Gill and Bradstock 1995).
In periodically burned landscapes such refugia offer persistent habitat diversity, as well as areas around unburned trees, logs, and surrounding litter where organisms averse to fire, such as specific spiders, ants, other arthropods, and fungi, are likely to persist (York 1999; Andrew et al. 2000; Dahlberg 2002). When one management is dominant, establishment of areas consistently managed a different way adds beneficial diversity. Unburned refugia in burned landscapes may be disproportionately valuable to specialists because burning tends to "simplify" communities (i.e. reduce diversity) (Lamotte 1975; Collins et al. 1998; Cleary and Grill 2004) and because many specialized invertebrates are rare or absent in places periodically burned (Swengel 1998b; Gandhi et al. 2001; Nekola 2002). Other studies have recommended non-fire refugia and/or alternative managements to fire as a conservation measure for grassland snails, numerous prairie arthropods, and boreal forest invertebrates (Niemela 1997; Harper et al. 2000; Nekola 2002). In some cases, e.g. birds and some boreal forest beetles, no upper limit was apparent on how long a fire-free period would continue to benefit specialists (Gill and McCarthy 1998; Gandhi et al. 2001).

Never-burned refugia are likely to be even more valuable for conservation than refugia in formerly firemanaged vegetation. Large numbers of species may be lost from a site when it is burned for the first time in recent history. Areas extensively surveyed for Lepidoptera prior to the first recent burn experienced an $81 \%$ reduction in species richness in the year after fire (Cleary and Grill 2004), and $>35 \% 5$ years later in an area considered naturally fire-prone (Powell 2005), compared to pre-fire diversity. In a study of regularly burned prairies, species highly sensitive to fire were not found (Panzer 2002), suggesting they were extirpated before the study.

Previously burned areas can acquire some nonburned characteristics (e.g. recovery of regal fritillary 
at Muralt Bluff: see Results), but in this study, formerly burned units began functioning as refugia only 6-8 years after last fire and continued to increase in benefit for years after that. Regal fritillaries at Muralt Bluff significantly declined to their nadir in 1998 (Fig. 8, Table 3), which was fire year-class 7 for the refugium (last burned in 1991), then increased significantly after that (Table 3). At Crex Meadows, Karner blue abundance in the refugium (last burned in 1988) surpassed the mean index at the comparisons in 1994 (fire year-class 6; Fig. 5). But some species may never come back (e.g. Ottoe skipper at Muralt Bluff). Conversely, an inadvertently burned refugium may lose its benefits for many years or even permanently for some species. To ensure their unburned status, the locations and purpose of refugia should be communicated to all persons involved in site management and included in written management plans. Refugia need to be protected from both planned and unplanned fires (e.g. maintaining firebreaks to keep fire out as well as control management fires within a unit).

Alternative managements cost less than fire. Brush cutting and mowing routinely occur in the prairies and barrens in this study (pers. obs.) whether units are burned or not. Fire uses most of the same equipment as brush cutting and haying (e.g. tractors to cut brush or mow or disk within firebreaks) but requires additional equipment (e.g. water trucks, drip torches), more staff, and higher insurance costs. Burning is more constrained by seasonal timing (e.g. narrow period after spring thaw dries out but before greenup), weather conditions, and safety issues (e.g. smoke drift). Establishing the refugium continues alternative managements that already occur in these sites, but eliminates the cost of burning. Many prairies have pre-conservation farming histories and are near farms. Periodic haying of prairie preserves produces revenue (e.g. US $\$ 12.35 /$ ha in 1993 , T. Toney pers. commun.) usually via leases to farmers who supply the equipment and manpower. Unintensive grazing can also replace burning, and can produce enough money to replace setup costs on preserves (Manitoba Natural Resources et al. 2001, J. Keir, pers. comm.).
We recommend that non-fire refugia for Lepidoptera conservation be permanent, placed where the most specialized species will benefit, and managed unintensively with mowing, brush-cutting, and the like if needed. Some sites (as opposed to units within sites) with unusually high richness and abundance of fire-sensitive specialists are particularly good candidates for large non-fire refugia. Fortunately, relatively large refugia existed throughout this study in the prairie (Hogback) and barren (Bauer-Brockway) with the richest specialist butterfly fauna recorded in our surveys in those vegetation types in Wisconsin (Swengel 1998a). These two sites may function as "paleoenvironments" (Brown 1997, Gandhi et al. 2001) that are especially important to conserve for their unusually high "paleobiodiversity" (Samways et al. 2006). Our study indicates that legal regulation for listed species that encourages permanent non-fire refugia and more emphasis on mechanical than fire management have benefited listed species as well as co-occurring unlisted specialist Lepidoptera. These regulations were developed and implemented based on the biology of individual species, but had multiplespecies benefits.

Acknowledgements We are very grateful to funders of parts of this research: Lois Almon Small Grants Research Program, Wisconsin Department of Natural Resources, U.S. Fish and Wildlife Service, Jed Bromfield and Henya Rachmiel, and Drs. William and Elsa Boyce. We appreciate that staff from the Wisconsin Department of Natural Resources provided data on management history for Buena Vista, Crex Meadows, and Muralt Bluff. We thank the Zinkle family for allowing us access to Hogback when it was privately owned. We especially thank the managers, particularly Tim Beyer, Pete Engman, Randy Hoffman, Jim Keir, Gene Kohlmeyer, Paul Kooiker, and Ed Vlach (Wisconsin Department of Natural Resources); Nancy Braker and Steve Richter (The Nature Conservancy); Gary Felder; Jon Schweitzer and Jim Zahasky (Jackson County Forest); as well as Cathy Bleser, Kathy Kirk, and Dave Lentz (Wisconsin Department of Natural Resources) and Cathy Carnes and Mike Engel (U.S. Fish and Wildlife Service), for including permanent non-fire refugia in their programs, enabling us to study them. We thank the editors and two reviewers for numerous helpful comments.

\section{Appendix 1}

Survey dates at refugium and comparison units/sites

\begin{tabular}{|c|c|c|c|}
\hline & \multicolumn{3}{|c|}{ Crex Meadows/Burnett County Forest ${ }^{\mathrm{a}}$} \\
\hline & Summer butterflies & Spring butterflies & Phlox moth \\
\hline Refugium unit & 20-31 July ${ }^{\mathrm{b}}$ & 17 May-13 June ${ }^{c}$ & 22 May-13 June ${ }^{\mathrm{d}}$ \\
\hline Comparison units & 20-31 July ${ }^{\mathrm{b}}$ & 17 May-13 June ${ }^{c}$ & 22 May-13 June \\
\hline
\end{tabular}


Appendix continued

\begin{tabular}{|c|c|c|}
\hline & \multicolumn{2}{|c|}{ Southern Wisconsin Prairie/Grassland ${ }^{\mathrm{e}}$} \\
\hline & Regal fritillary & Ottoe skipper \\
\hline Muralt Bluff, $\mathrm{g}$ & 3 Jul-8 Aug & 3 Jul-11 Aug \\
\hline \multicolumn{3}{|l|}{ Comparison sites } \\
\hline Hogback $^{\mathrm{f}, \mathrm{h}}$ & 29 Jun-11 Aug & 29 Jun-6 Aug \\
\hline Thomson complex ${ }^{\mathrm{f}, \mathrm{i}}$ & 6 Jul-1 Sep & - \\
\hline \multirow[t]{3}{*}{ Buena Vista $^{\mathrm{j}}$} & 25 Jun-26 Aug & - \\
\hline & \multicolumn{2}{|c|}{ Central Wisconsin Barrens ${ }^{\mathrm{e}}$} \\
\hline & Karner blue & Frosted elfin \\
\hline Bauer-Brockway & 8 Jul-20 Aug ${ }^{\mathrm{k}}$ & 2 May-12 Jun ${ }^{1}$ \\
\hline Comparison sites & 8 Jul-20 Aug ${ }^{\mathrm{m}}$ & 2 May-12 Jun ${ }^{1}$ \\
\hline
\end{tabular}

a Single survey date per year at refugium and comparison units

b 1991-2005 except 4 (of 14) comparison units missing a survey in 1996 due to inclement weather; Karner blue recorded regularly in all monitoring subsites; mottled duskywing recorded in site every year except 1999, in monitoring subsite(s) each year except 1994, 1999, and 2005, and at least once in all monitoring subsites

c 1994-95, 1999-2000, 2002-04 at refugium and 7 comparison subsites (8 units)

d 1994, 1998-2000, 2002-05 except 2 of 5 comparison units (1 of 4 subsites) missing a survey in 2005

e Multiple surveys per site in many years

${ }^{\mathrm{f}}$ For extreme early or late dates, surveys also occurred later or earlier in flight period, respectively

g 1990-2005; regal fritillary recorded every year

h 1992-2005; regal fritillary recorded every year

i 1990-2005 at Thomson original and Thousand's II (regal fritillary recorded most years); 1992-2005 at Thomson subsequent (regal fritillary recorded every year)

j Peak survey determined individually for each of 12 equal-sized units (800 m square transect per unit); 1997-2005; regal fritillary presence ranged from $4 / 9$ to $9 / 9$ years, mean 7.4 years per unit)

k 1992-2005 in all 5 units except missing a survey in unit 1 in 1993 and 1996-98 and in 5 in 1992-94; later part of survey period also suitable for Leonard's skipper

${ }^{1}$ 1992-2005 in all 5 units except some units not effectively surveyed in 1993 due to persistent cool rainy weather; survey period also suitable for Olympia marble, gorgone checkerspot, Persius duskywing, cobweb and dusted skippers, and phlox moth; frosted elfin recorded at all sites analyzed for that species here, but in all years at only one site, and at some sites only in one to a few years (see Swengel and Swengel 2000), with presence in the units at Bauer-Brockway ranging from 6/13 to 11/13 years during 1992-2005 except 1993; mean 8.4 years

m 11 comparison sites 1999-2005; 7 comparison sites 1992-2005

\section{References}

Anderson RC (1982) An evolutionary model summarizing the roles of fire, climate, and grazing animals in the origin and maintenance of grasslands: an end paper. In: Estes JR, Tyrl RJ, Brunken JN (eds) Grasses and grasslands: systematics and ecology. University of Oklahoma Press, Norman, pp 297-308

Andrew N, Rodgerson L, York A (2000) Frequent fuel-reduction burning: the role of logs and associated leaf litter in the conservation of ant biodiversity. Austral Ecol 25:99-107

Baker RG, Bettis EA III, Schwert DP et al (1996) Holocene paleoenvironments of northeast Iowa. Ecol Monogr 66:203-234

Borchert JR (1950) Climate of the central North American grasslands. Annl Assoc Am Geographers 40:1-39

Borgerding EA, Bartelt GA, McCown WM (1995) The future of pine barrens in northwest Wisconsin: a workshop summary. PUBL-RS-913-94. Wisconsin Department of Natural Resources, Madison

Borth B (1992) Regal fritillary butterflies. Newsl Wisc Entomol Soc 19(2):10-11

Brown KS Jr (1997) Diversity, disturbance, and sustainable use of neotropical forests: insects as indicators for conservation monitoring. J Insect Conserv 1:25-42

Bureau of Endangered Resources (1999) The endangered and threatened invertebrates of Wisconsin. Wisconsin Department of Natural Resources, Madison

Cleary DFR, Grill A (2004) Butterfly response to severe ENSO-induced forest fires in Borneo. Ecol Entomol 29:666-676

Clements FE (1916) Plant succession: an analysis of the development of vegetation. Carnegie Institute, Washington DC

Cole KL, Taylor RS (1995) Past and current trends of change in a dune prairie/oak savanna reconstructed through a multiplescale history. J Veget Sci 6:399-410

Collins SL, Knapp AK, Briggs JM et al (1998) Modulation of diversity by grazing and mowing in native tallgrass prairie. Science 280:745-747 
Curtis JT (1959) The vegetation of Wisconsin. University of Wisconsin Press, Madison

Dahlberg A (2002) Effects of fire on ectomycorrhizal Fungi in Fennoscandian boreal forests. Silva Fennica 36:69-80

Dana R (1991) Conservation management of the prairie skippers Hesperia dacotae and Hesperia ottoe: basic biology and threat of mortality during prescribed burning in spring. Minnesota Agric Exp Stn Bull 594-1991, University of Minnesota, St. Paul

Dennis RLH (2004) Just how important are structural elements as habitat components? Indications from a declining lycaenid butterfly with priority conservation status. J Insect Conserv 8:37-45

Dieffenbacher-Krall A (1996) Paleo- and historical-ecology of the Cutler Grasslands, Cutler, Maine (USA): implications for future management. Nat Areas J 16:3-13

Ellsworth JW, McComb BC (2003) Potential effects of passenger pigeon flocks on the structure and composition of presettlement forests of eastern North America. Conserv Biol 17:1548-1558

England RE, DeVos A (1969) Influence of animals on pristine conditions on the Canadian grasslands. J Range Manage 22:87-94

Gandhi KJK, Spence JR, Langor DW et al (2001) Fire residuals as habitat reserves for epigaeic beetles (Coleoptera: Carabinidae and Staphylinidae). Biol Conserv 102:131-141

Gandhi KJK, Spence JR, Langor DW et al (2003) Harvest retention patches are insufficient as stand analogues of fire residuals for litter-dwelling beetles in northern coniferous forests. Can J For Res 34:1319-1331

Gill AM, Bradstock R (1995) Extinction of biota by fires. In: Bradstock RA, Auld TD, Keith DA et al (eds) Conserving biodiversity: threats and solutions. Surrey Beatty and Sons, pp 309-322

Gill AM, McCarthy MA (1998) Intervals between prescribed fires in Australia: what intrinsic variation should apply? Biol Conserv 85:161-169

Harper MG, Dietrich CH, Larimore RL, Tessene PA (2000) Effects of prescribed fire on prairie arthropods: an exclosure study. Nat Areas J 20:325-335

Higgins KF (1984) Lightning fires in North Dakota grasslands and in pine-savanna lands of South Dakota and Montana. J Range Manage 37:100-103

Higgins KF (1986) Interpretation and compendium of historical fire accounts in the northern Great Plains. U.S. Fish and Wildlife Service Resource Publ. 161, Washington DC

Howe HF (1994) Managing species diversity in tallgrass prairie: assumptions and implications. Conserv Biol 8:691-704

King JE (1981) Late quaternary vegetational history of Illinois. Ecol Monogr 51:43-62

Knapp AK, Blair JM, Briggs JM et al (1999) The keystone role of bison in North American tallgrass prairie. BioScience 49:39-50

Knutson RL, Kwilosz JR, Grundel R (1999) Movement patterns and population characteristics of the Karner blue butterfly (Lycaeides melissa samuelis) at Indiana Dunes National Lakeshore. Nat Area J 19:109-120

Kwilosz JR, Knutson RL (1999) Prescribed Fire Management of Karner blue butterfly habitat at Indiana Dunes National Lakeshore. Nat Areas J 19:98-108

Lamotte M (1975) The structure and function of a tropical savanna ecosystem. In: Golley FB, Medina E (eds) Tropical ecological systems: trends in terrestrial and aquatic research. Springer-Verlag, Berlin, pp 179-222

Larson F (1940) The role of the bison in maintaining the short grass plains. Ecology 21:113-121
Manitoba Natural Resources, Environment Canada, World Wildlife Fund Canada, and Critical Wildlife Habitat Program. 2001. Manitoba Prairie Conservation Action Program 1996-2001. 32 pages. http://www.gov.mb.ca/conservation/ wildlife/managing/pcap.pdf

McCabe TO (1981) The Dakota skipper, Hesperia dacotae, (Skinner): range and biology, with special reference to North Dakota. J Lepid Soc 35:179-193

Moore CT (1988) Mid-nineteenth century short grass expansion in the central and southern Great Plains. In: Davis A Stanford G (eds) The prairie: roots of our culture; foundation of our Economy. Proceedings of the 10th North American Prairie Conference. Native Prairies Association of Texas, Dallas, section 01.04

Nekola J (2002) Effects of fire management on the richness and abundance of central North American grassland land snail faunas. Anim Biodiv Conserv 25(2):53-66

Niemala J (1997) Invertebrates and boreal forest management. Conserv Biol 11:601-610

New TR, Van Praagh BD, Yen AL (2000) Fire and the management of habitat quality in an Australian Lycaenid butterfly, Paralucia pyrodiscus lucida Crosby, the Eltham copper. Metamorphosis 11:154-163

Nuzzo VA (1986) Extent and status of midwest oak savanna: presettlement and 1985. Nat Areas J 6:6-36

Opler PA (1981) Management of prairie habitats for insect conservation. Nat Areas J 1:3-6

Orwig T (1992) Loess hills prairies as butterfly survivia: opportunities and challenges. In: Smith DD, Jacobs CA (eds) Proceedings of the Twelfth North American Prairie Conference 1990. University of Northern Iowa, Cedar Falls, pp 131-135

Panzer R (1988) Managing prairie remnants for insect conservation. Nat Areas J 8:83-90

Panzer R (2002) Compatibility of prescribed burning with the conservation of insects in small, isolated prairie preserves. Conserv Biol 16:1296-1307

Panzer R (2003) Importance of in situ survival, recolonization, and habitat gaps in the postfire recovery of fire-sensitive prairie insect species. Nat Areas J 23:14-21

Pollard E (1977) A method for assessing changes in abundance of butterflies. Biol Conserv 12:115-133

Pollard E, Yates TJ (1992) The extinction and foundation of local butterfly populations in relation to population variability and other factors. Ecol Entomol 17:249-254

Pollard E, Yates TJ (1993) Monitoring butterflies for ecology and conservation. Chapman and Hall, London

Powell JA (2005) Recovery of Lepidoptera (moths and butterflies) following a wildfire at Inverness Ridge in central coastal California. In: Vision fire: Lessons learned from the October 1995 fire. Point Reyes National Seashore, CA, and U.S. Department of the Interior, Washington, DC, pp 21-32

Russell EWB (1983) Indian-set fires in the forests of the northeastern United States. Ecology 64:78-88

Samways MJ, Ponel P, Andrieu-Ponel V (2006) Paleobiodiversity emphasizes the importance of conserving landscape heterogeneity and connectivity. J Insect Conserv 10:215-218

Sands DPA, New TR (2002) The action plan for Australian butterflies. Environment Australia, Canberra

Sauer C (1950) Grassland climax, fire and management. J Range Manage 3:16-20

Schlicht DW (2001) The decline of the Arogos skipper (Atrytone arogos) at Prairie Coteau in Pipestone County, Minnesota. In: Bernstein NP, Ostrander IJ (eds) Proceedings of the 17th North American Prairie Conference. Iowa Community College, Mason City, pp 197-200 
Schlicht DW, Orwig TT (1992) Sequential use of niche by prairie obligate skipper butterflies (Lepidoptera: Hesperiidae) with implications for management. In: Smith DD, Jacobs CA (eds) Proceedings of the Twelfth North American Prairie Conference 1990. University of Northern Iowa, Cedar Falls, pp 137-139

Schweitzer DF (1994) Recovery goals and methods for Karner blue butterfly populations. In: Andow DA, Baker RJ, Lane CP (eds) Karner Blue Butterfly: a symbol of a vanishing landscape. Misc. Publ. 84-1994, Minnesota Agric Expt Stn, University of Minnesota, St. Paul, pp 185-193

Shuey JA (1997) Dancing with fire: ecosystem dynamics, management, and the Karner blue (Lycaeides melissa samuelis Nabokov) (Lycaenidae). J Lepid Soc 51:263-269

Solecki MK, Toney T (1986) Characteristics and management of Missouri's public prairies. In: Clambey GK, Pemble RH (eds) The prairie-past, present and future: Proceedings of the Ninth North American Prairie Conference. Tricollege University Center for Environmental Studies, Fargo, ND, pp 168-170

Stewart OC (1956) Fire as the first great force employed by man. In: Thomas WL (ed) Man's role in changing the face of the Earth. University of Chicago Press, Chicago, pp 115-133

Swengel AB (1996a) Effects of fire and hay management on abundance of prairie butterflies. Biol Conserv 76:73-85

Swengel AB (1996b) Observations of Incisalia irus (Lepidoptera: Lycaenidae) in central Wisconsin 1988-95. Great Lakes Entomol 29:47-62

Swengel AB (1997) Habitat associations of sympatric violetfeeding fritillaries (Euptoieta, Speyeria, Boloria) (Lepidoptera: Nymphalidae) in tallgrass prairie. Great Lakes Entomol 30:1-18

Swengel AB (1998a) Comparisons of butterfly richness and abundance measures in prairie and barrens. Biodiv Conserv 7:1639-1659

Swengel AB (1998b) Effects of management on butterfly abundance in tallgrass prairie and pine barrens. Biol Conserv 83:77-89

Swengel AB (2001) A literature review of insect responses to fire, compared to other conservation managements of open habitat. Biodiv Conserv 10:1141-1169

Swengel AB, Swengel SR (1996) Factors affecting abundance of adult Karner blues (Lycaeides melissa samuelis) (Lepidoptera: Lycaenidae) in Wisconsin surveys 1987-95. Great Lakes Entomol 29:93-105

Swengel AB, Swengel SR (1999) Observations on Schinia indiana and Schinia lucens in the midwestern United States (Lepidoptera: Noctuidae). Holarctic Lepid 6:11-21
Swengel AB, Swengel SR (2000) Variation in timing and abundance of elfins (Callophrys) (Lepidoptera: Lycaenidae) in Wisconsin during 1987-1999. Great Lakes Entomol 33:45-68

Swengel AB, Swengel SR (2001a) A ten-year study to monitor populations of the regal fritillary, Speyeria idalia, (Lepidoptera: Nymphalidae) in Wisconsin, USA. Great Lakes Entomol 34:97-115

Swengel AB, Swengel SR (2001b) Effects of prairie and barrens management on butterfly faunal composition. Biodiv Conserv 10:1757-1785

Swengel AB, Swengel SR (2005) Long-term population monitoring of the Karner blue (Lepidoptera: Lycaenidae) in Wisconsin, 1990-2004. Great Lakes Entomol 38:107-134

Thomas JA (1984) A quick method for estimating butterfly numbers during surveys. Biol Conserv 27:195-211

Toepfer JE (2003) Prairie chickens \& grasslands: 2000 and beyond. Septon G (ed) Society for Tympanuchus Cupido Pinnatus, Ltd. Elm Grove, WI, USA

Transeau EN (1935) The prairie peninsula. Ecology 16:423-437

Umbanhowar CE Jr (1996) Recent fire history of the northern Great Plains. Am Midland Nat 135:115-121

Vogl RJ (1974) Effect of fire on grasslands. In: Kozlowski TT, Ahlgren CE (eds) Fire and ecosystems. Academic Press, New York, pp 139-194

U.S. Fish and Wildlife Service (2003) Karner blue recovery plan (Lycaeides melissa samuelis). Department of the Interior, Fort Snelling, MN

Weaver JE (1954) North American prairie. Johnsen Publishing Co., Chicago

Wisconsin Chapter of The Nature Conservancy (1988) The places we save. Madison, WI, USA

Wisconsin Chapter of The Nature Conservancy (2006) The nature conservancy. http://www.nature.org

Wisconsin County Forest Association (2006) Wisconsin county forests: unique to the nation. http://www.wisconsincountyforests.com

Wisconsin Department of Natural Resources (1998) Wisconsin DNR's public wildlife recreation land. Madison

Wisconsin Department of Natural Resources (2006) Wisconsin Department of Natural Resources. http://www.dnr.state.wi.us

York A (1999) Long-term effects of frequent low-intensity burning on the abundance of litter-dwelling invertebrates in coastal blackbutt forests of southern Australia. J Insect Conserv 3:91-199 